\title{
STUDY OF KNOWLEDGE AND PRACTICE ABOUT CONTRACEPTION AMONG WOMEN SEEKING MEDICAL TERMINATION OF PREGNANCY
}

\section{Gynaecology}

Dr Sanjaykumar B Assistant Professor, Dept. of OBGY, Government Medical College, Aurangabad. Pagare* *Corresponding Author

\section{Dr Prashant Bhingare \\ Dr. Shrinivas Gadappa \\ Dr. Sonali Deshpande}

Associate professor, Dept.of OBGY, Government Medical College, Aurangabad.

Professor, Dept.of OBGY, Government Medical College, Aurangabad.

Associate professor, Dept. of OBGY, Government Medical College, Aurangabad.

\section{ABSTRACT}

OBJECTIVE :- To assess the knowledge, attitude and practices about contraception among women seeking induced abortion. Material $\boldsymbol{\&}$ Methods: This is a cross sectional study conducted in Dept.of OBGY,GMCH, Aurangabad between the period October 2019 to March 2020 using predesigned pretested questionnaire in women seeking medical termination of pregnancy. Observation:-Around $90 \%$ women were aware about contraception. Knowledge regarding tubectomy was more (77.66\%) than other methods of contraception. Around $60 \%$ women were willing to use contraception and $70 \%$ women accepted contraception after counselling at the time of availing abortion services. Conclusion: Overall awareness of contraception was about $90 \%$. Overall acceptance of contraception was $70 \%$ and utilization of tubectomy, as a permanent method of contraception was high due to government initiatives and incentives. Fear of side effects of contraception was an important factor for contraception denial. Husband's support in the choice of contraception plays an important role.

\section{KEYWORDS}

contraception,medical termination of pregnancy,tubectomy,Intrauterine contraceptive device

\section{INTRODUCTION:}

India is a developing country and is still among overly populated countries in the world.Abortion may be the indication of "unmet needs" or a failed family planning; both leading to unwanted pregnancy and a desire to get it terminated. Though many methods of contraception are available to all the people, many women are yet to take the initiative to implement in practice for mainly two reasons social and family background. In India, the women opting for over the counter drugs for abortion are much more than for contraception.Provision of effective reversible contraception following abortion is recognised by the World Health Organization as a key component of integrated care [1].Ideally, all women should receive information about, and be offered, effective contraception as part of their care, as delayed provision has been shown to be associated with a higher risk of a repeat unintended pregnancy[2].According to UN projections, India's population will reach 1.53 billion by the year 2050 and will be the highest population in the world[3]. To reduce maternal morbidity and mortality associated with illegal abortions, termination of pregnancy has been legalized in India when government of India passed the medical termination act in 1971. To plan the number of children and spacing is a fundamental women reproductive right. The number of unintended pregnancies is high and unacceptable in developing countries like India [4]. Repeated termination of pregnancy has a short-term and long-term deleterious effect on mothers health. Contraceptive advice and counselling should be an important part of an obstetrician's responsibility. Encouraging eligible couples to use effective contraceptive method will help to reduce induced abortions. Many women face significant barriers to contraception access and utilization that result in adverse health effects of early pregnancy and childbirth.Ours is Model comprehensive abortion care centre providing safe abortion services in Marathwada region of Maharashtra. As Marathwada region is economically backward and this region is characterized by drought events during certain periods of the year. A large portion of floating population migrates to Western Maharashtra to work in sugarcane farms. A consistent use of family planning methods is difficult in this population even though women may be willing to use contraception. Further, if widely used, it may have a strong impact on family planning program me and help prevent unintended pregnancies and its potential consequences. There severe limitations in the access to safe and effective methods of contraception and safe abortion services. There is a need for an urgent response in reducing the "unmet needs" for contraception and to improve access to contraception, abortion information, and services in this group.Hence the present study was carried to access the awareness about contraception, reasons for acceptance and denial of contraception and to identify area of confusion that might serve as an important target to educational intervention.

Material and method :- The present cross sectional study was carried out among women seeking abortion care in the Department of OBGY, GMCH Aurangabad from October 2019 to March 2020. After explaining the purpose of the study and after obtaining consent, willing women were enrolled in the study. Counseling regarding comprehensive abortion care and abortion services was provided even though she denied to participate in the study. The baseline sociodemographic parameters were noted.The interview for this study was conducted by a trained medical practitioner and involved a face-toface interview using predesigned pretested questionnaire.Different questions were asked to access their knowledge, attitudes \& practices towards family planning methods. The questionnaire on contraception assesses (i) knowledge and its source, (ii) practice of contraception current choice of contraception and (iii) attitude toward using contraceptive methods - reasons for not using or using and reasons for delaying pregnancy. The questionnaire included 6 questions regarding demographic information, 5, 7 and 5 questions about knowledge, attitude and practices of induced abortions respectively. The questions were explained to the women and their responses were entered in the respective columns of the questionnaire. The questionnaire was given on the spot to the respondent. The data was analyzed by simple proportion and percentages.

\section{Observations:}

Table1:Baseline characteristics:

\begin{tabular}{|c|c|c|c|}
\hline \multicolumn{2}{|c|}{ Baseline Characteristics } & $\begin{array}{c}\text { No.of women } \\
\mathrm{N}=300\end{array}$ & Percentage \\
\hline \multirow{3}{*}{ Age in years } & $21-30$ & 174 & 58 \\
\cline { 2 - 4 } & $31-40$ & 120 & 40 \\
\cline { 2 - 4 } & $\geq 40$ & 06 & 2 \\
\hline Parity & $\mathrm{P} 0$ & 02 & 0.67 \\
\cline { 2 - 4 } & $\mathrm{P} 1$ & 160 & 53.33 \\
\cline { 2 - 4 } & $\mathrm{P} 2-4$ & 134 & 44.67 \\
\cline { 2 - 4 } & $\geq \mathrm{P} 5$ & 04 & 1.33 \\
\hline
\end{tabular}




\begin{tabular}{|c|c|c|c|}
\hline \multirow{3}{*}{$\begin{array}{c}\text { Socioeconom } \\
\text { ic Status* }\end{array}$} & Upper & 5 & 1.66 \\
\cline { 2 - 4 } & Upper Middle & 15 & 5 \\
\cline { 2 - 4 } & Lower Middle & 60 & 20 \\
\cline { 2 - 4 } & Upper Lower & 160 & 53.33 \\
\cline { 2 - 4 } & Lower & 60 & 20 \\
\hline Residence & Urban & 140 & 46.66 \\
\cline { 2 - 4 } & Rural & 160 & 53.33 \\
\hline \multirow{3}{*}{$\begin{array}{c}\text { Educational } \\
\text { Status }\end{array}$} & Primary & 86 & 28.66 \\
\cline { 2 - 4 } & Secondary & 135 & 45 \\
\cline { 2 - 4 } & Graduate & 75 & 25 \\
\cline { 2 - 4 } & Postgraduate & 04 & 1.33 \\
\hline \multirow{2}{*}{$\begin{array}{c}\text { Employment } \\
\text { Status }\end{array}$} & Unemployed & 209 & 69.66 \\
\cline { 2 - 4 } & Employed & 91 & 30.33 \\
\hline $\begin{array}{c}\text { Gestational } \\
\text { Age at the } \\
\text { time of } \\
\text { interview } \\
\text { with weeks }\end{array}$ & $\leq 12$ & 230 & 23.34 \\
\cline { 2 - 4 } & $>12$ & 70 & \\
\hline \multirow{2}{*}{. } & & & \\
\hline
\end{tabular}

* Modified Kuppuswami's scale

Table1:Table shows the Socio-demographic characteristics of study participants.Around 58\% participants were in the age group of 21-30 years and $46 \%$ were multiparas .Lower socioeconomic status was noted in $90.33 \%$ participants and $53.33 \%$ coming from rural area to hospital for seeking MTP. Around $45 \%$ were educated up to secondary school and only $30.33 \%$ participants were employed.Around gestational age $\leq 12$ weeks was reported in $76.66 \%$.

Table2: Knowledge of women about contraception:

\begin{tabular}{|c|c|c|c|}
\hline \multicolumn{2}{|c|}{ Knowledge } & \multicolumn{2}{|c|}{ Response* } \\
\hline & & YES & NO \\
\hline \multicolumn{2}{|c|}{ Heard about Family Planning } & 270 & 90 \\
\hline \multirow{7}{*}{$\begin{array}{l}\text { Methods of } \\
\text { contraception } \\
\text { known* }\end{array}$} & Tubectomy & 233 & 77.66 \\
\hline & Vasectomy & 20 & 6.66 \\
\hline & Oral Contraceptive Pills & 184 & 61.33 \\
\hline & Condom & 206 & 68.66 \\
\hline & $\begin{array}{c}\text { Intrauterine } \\
\text { contraceptive device }\end{array}$ & 216 & 72 \\
\hline & Injectable contraception & 26 & 8.66 \\
\hline & Saheli (Centchroman) & 02 & 0.66 \\
\hline \multirow{8}{*}{$\begin{array}{c}\text { Source of } \\
\text { contraceptive } \\
\text { information* }\end{array}$} & Television & 180 & 60 \\
\hline & Radio & 110 & 36.66 \\
\hline & Newspapers & 56 & 18.66 \\
\hline & Magazines & 10 & 3.33 \\
\hline & Health care Providers & 204 & 68 \\
\hline & Family members & 164 & 54.66 \\
\hline & Friends & 230 & 76.66 \\
\hline & $\begin{array}{c}\text { Non-governmental } \\
\text { organization }\end{array}$ & 04 & 1.33 \\
\hline \multirow{3}{*}{$\begin{array}{c}\text { Knows access } \\
\text { to family planning } \\
\text { services* }\end{array}$} & $\begin{array}{c}\text { Health } \\
\text { centres/Govt.hospitals }\end{array}$ & 210 & 70 \\
\hline & Private Hospitals & 126 & 42 \\
\hline & Health care providers & 204 & 68 \\
\hline \multirow{6}{*}{$\begin{array}{l}\text { Knows about the } \\
\text { method of family } \\
\text { panning that can } \\
\text { used immediately } \\
\text { after abortion* }\end{array}$} & Tubectomy & 210 & 70 \\
\hline & Oral contraceptive pills & 150 & 50 \\
\hline & $\begin{array}{c}\text { Intrauterine } \\
\text { contraceptive device }\end{array}$ & 180 & 60 \\
\hline & Injectable contraception & 00 & 00 \\
\hline & Condom & 210 & 70 \\
\hline & Don't know & 90 & 30 \\
\hline
\end{tabular}

*one woman may have knowledge about more methods

Table 2:Around $90 \%$ of the study participants were aware about the family planning. Tubectomy was known to $77.66 \%$ study participants followed by Oral contraceptive pills $(61.33 \%)$ and intrauterine contraceptive device to $72 \%$.In $60 \%$ participants, the source of information was television. Around $70 \%$ were aware that the contraceptive services were available in health centre/government hospital. Only $30 \%$ participants were totally unaware about the methods of contraception that can be used immediately after abortion.

Table3:Attitude towards Methods of family planning:

\begin{tabular}{|c|c|c|c|}
\hline \multicolumn{2}{|c|}{ Attitude towards family planning } & Frequency* & Percentage \\
\hline $\begin{array}{l}\text { Use of contraception } \\
\text { for spacing/limiting } \\
\text { family }\end{array}$ & 267 & 89 & \\
\hline $\begin{array}{l}\text { Fear regarding side } \\
\text { effects of } \\
\text { contraception }\end{array}$ & 156 & 52 & \\
\hline $\begin{array}{c}\text { Feels difficult to } \\
\text { access contraceptive } \\
\text { services }\end{array}$ & 121 & 40.33 & \\
\hline $\begin{array}{c}\text { Willing to use } \\
\text { contraception after } \\
\text { MTP }\end{array}$ & 180 & 60 & \\
\hline $\begin{array}{l}\text { Use of contraception } \\
\text { for health benefit. }\end{array}$ & 25 & 8.33 & \\
\hline $\begin{array}{l}\text { Encourage practice } \\
\text { of contraception in } \\
\text { family }\end{array}$ & 136 & 45.33 & \\
\hline \multirow{4}{*}{$\begin{array}{l}\text { Discussion about the } \\
\text { methods of } \\
\text { contraception* }\end{array}$} & Husband & 213 & 71 \\
\hline & Family & 120 & 40 \\
\hline & Friends & 186 & 62 \\
\hline & HCPs & 207 & 69 \\
\hline
\end{tabular}

*The total percentage is more than 100 because some participants might be citing more than one reason

Table3:Use of contraception for spacing/limiting the family was agreed by $89 \%$ participants and $60 \%$ participants were willing to use contraceptives after abortion.Majority women (71\%) discussed about the methods of contraception before choosing any method.

Table 4:Practices toward family Panning Methods:

\begin{tabular}{|c|c|c|c|}
\hline Practices towards family & Frequency & Per & entage \\
\hline Willing to use contraception & Yes & 210 & 70 \\
\hline immediat & No & 90 & 30 \\
\hline Reasons for using & Wants spacing family & 120 & 40 \\
\hline & Wants limiting family & 90 & 30 \\
\hline & $\begin{array}{l}\text { Avoid unwanted } \\
\text { pregnancy }\end{array}$ & 220 & 73.33 \\
\hline & $\begin{array}{l}\text { Scocioeconomic } \\
\text { reasons }\end{array}$ & 221 & 73.67 \\
\hline & $\begin{array}{l}\text { Want improvement in } \\
\text { health }\end{array}$ & 25 & 8.33 \\
\hline & Avoid STDs & 2 & 0.66 \\
\hline Factors supporting use \& & Husband's choice & 210 & 70 \\
\hline & Free of cost & 220 & 73.33 \\
\hline & Minimal side effects & 124 & 41.33 \\
\hline & Advertise on Telemedia & 180 & 60 \\
\hline & $\begin{array}{c}\text { Positive feedback from } \\
\text { Family and friends }\end{array}$ & 124 & 41.33 \\
\hline Method opted as & Oral contraceptive Pills & 30 & 10 \\
\hline contra & $\begin{array}{c}\text { Injectable hormonal } \\
\text { contraception }\end{array}$ & 02 & 0.66 \\
\hline & IUCD & 78 & 26 \\
\hline & Condom & 10 & 3.33 \\
\hline & Female Sterilization & 90 & 30 \\
\hline $\begin{array}{l}\text { Reasons for refusal of } \\
\text { contraception* }\end{array}$ & $\begin{array}{l}\text { Doesn't wants } \\
\text { immediate } \\
\text { contraception }\end{array}$ & 25 & 8.33 \\
\hline
\end{tabular}




\begin{tabular}{|c|c|c|c|}
\hline \hline & Fear of side effects & 52 & 17.33 \\
\cline { 2 - 4 } & $\begin{array}{c}\text { Not able to take } \\
\text { decision }\end{array}$ & 12 & 4 \\
\cline { 2 - 4 } & $\begin{array}{c}\text { Resistance by family } \\
\text { members }\end{array}$ & 22 & 7.33 \\
\cline { 2 - 4 } & $\begin{array}{c}\text { Husband works out of } \\
\text { town }\end{array}$ & 05 & 1.66 \\
\hline
\end{tabular}

*one woman may have many reasons

Table 4: After counselling,70\% women were ready to accept contraception. The most common reason for using contraception was socioeconomic reason in $76.33 \%$.Husband's choice $(70 \%)$ and free of $\operatorname{cost}(73.33 \%)$ were the important factors supporting use and choice of contraception. Tubectomy was the preferred method of contraception after abortion in $30 \%$ followed by IUCD in $26 \%$. The main reason for refusal was fear of side effects in $17.33 \%$.

Discussion:: Contraceptive utilization is a practice that helps individuals or couples to avoid unwanted pregnancy. Even though there is the widespread availability of contraceptives, induced abortion remains an alarming public health problem.Contraception is an essential element of high-quality abortion care. However, women seeking abortion often leave health facilities without receiving contraceptive counselling or methods, increasing their risk of unintended pregnancy.The World Health Organization (WHO) advises that 'all women should receive contraceptive information and be offered counseling for and methods of postabortion contraception, including emergency contraception, before leaving the health care facility' following abortion [5]. A single centred study involving only women seeking medical termination of pregnancy was the limitation of this study and regarding the strength of the study was that it was conducted in a model care centre for comprehensive abortion care where trained providers for contraception counseling as well as abortion services were available.

In the present study,maximum participants were ( 58\%) were in the age of 21-30 years, $53.33 \%$ women were para one and $53.33 \%$ were belonging to lower socioeconomic status.Around $45 \%$ participants were educated up to secondary school.Similar socio-demographic profile was noted by Salma Jabin et al [6].

In present study, 70 participants reported after 12 weeks of gestation for medical termination of pregnancy.This depicts that there were many barriers to women for seeking abortion care services as they reported late for termination of pregnancy.Majority (77.66\%) participants were aware about tubectomy , $61.33 \%$ were aware about oral contraceptive pills and $68.66 \%$ were aware about condom as method of contraception.But knowledge about vasectomy(6.66\%) ,Injectible contraception $(8.66 \%)$ and centchorman $(0.66 \%)$ was very poor.Women feels shy to ask about contraception and feels it difficult to get information and services about contraception due to sociocultural barriers. Many women $(71 \%)$ were dependent on husband's choice for use of contraception $(73.33 \%)$ and use it only if available free of cost. In present study, $70 \%$ cases accepted contraception after counseling.Similar observation was made by Bamnia et al [7]. Knowledge of contraceptive methods is almost universal in India, with 99 percent of currently married women and men age 15-49 knowing at least one method of contraception.Female sterilization remains the most popular modern contraceptive method. Among currently married women age $15-49,36$ percent use female sterilization, followed by male condoms (6\%) and (4\%)pills [8].

In present study,awareness about contraception was $90 \%$ but acceptance of contraception was less around $70 \%$.Similar observation was made by Nataraja $\mathrm{H} \mathrm{G}$ et al [9]. This could be due to reason that the woman herself was not empowered to take the decision of contraceptive use and was dependent on the decision of husband and family members regarding family size and spacing in between children.Also she did not have liberty to choose the method and didn't take independent decision for herself.The main reason for undergoing abortion was need of limiting or spacing the family. The women were using abortion as a method of contraception

Conclusion: In present study, the overall awareness about contraception was $90 \%$ and overall uptake of contraception was $70 \%$ and utilization of tubectomy, a permanent method of contraception was high due to government initiatives and incentives . Fear of side effects of contraception was an important factor for contraception denial .Husband's support is essential in use of contraception. Couple counseling along with availability of wide range of contraceptive commodities especially long acting reversible contraception and the methods that can be used by male partner are essential to help women to prevent unintended pregnancy.

\section{REFERENCES:}

1. World Health Organization. Safe abortions: technical and policy guidance for health systems: World Health Organization; 2012

2. Raymond EG, Weaver MA, Tan Y-L, Louie KS, Bousiéguez M, Lugo-Hernández EM, e al. Effect of immediate compared with delayed insertion of etonogestrel implants on medical abortion efficacy and repeat pregnancy: a randomized controlled trial. Obstetrics \& Gynecology 2016;127(2):306-12. doi: 10.1097/AOG.000000000001274

3. K. Park. park Textbook of preventive and social medicine. 20th edition 2009. Banarasidas bhanot publisher 422-3.

4. Lakshmi Sheeshadri. Textbook of Essential of obstetrics. First edition 2017. Walters kluver publisher 355-96.

5. WHO Guidelines Approved by the Guidelines Review Committee. (2012). WHO recommendations: Optimizing health worker roles to improve access to key materna and newborn health interventions through task shifting. Geneva: World Health Organization(WHO) J

6. Salima Jabeen, Faiza Nasem, Sohaib Altaf, Nahed Fatima,Knowledge, Attitude an Practices about Induced Abortions among Women of Child Bearing age at Bahawalpur.Pakistan Journal of Medical and Health Sciences Vol.5, Issue 1, JAN-MAR 2011,147-151

Website: www.pjmhsonline.com

7. Archana Bamniya, Savitri Verma,The study of knowledge, attitude and practice abou abortion and technology at the tertiary centre in the region of Mewar,Rajasthan, India,International Journal of Reproduction, Contraception, Obstetrics and Gynecology, Int J Reprod Contracept Obstet Gynecol. 2018 Aug;7(8):33203324www.ijrcog.org

8. International Institute for Population Sciences (IIPS) and ICF. 2017. National Family Health Survey (NFHS-4), 2015-16: India. Mumbai: IIPS

9. Nataraja H G , Harshini V,Contraceptive Knowledge Attitude and Practice (KAP) among Women who were seeking for Termination of Pregnancy,Asian Journal of Biomedical and Pharmaceutical Sciences; 3 (23) 2013, 4-6. 